J. Perinat. Med. 1 (1973) 166

\section{Unexpected oxygen tensions in fetal acidosis}

\author{
Judith Lumley, Carl Wood \\ Department of Obstetrics and Gynaecology Monash University, \\ Queen Victoria Hospital, Melbourne, Victoria, Australia
}

Received November 9, 1972. Accepted January 30, 1973
Why are fetal scalp blood oxygen tensions such a poor guide to the state of the fetus? That they are "unhelpful" has been noted by Gulin, Escarcena and Pose [12], Kerenji, FALK, MEtTEL and WaLker [17] and ourselves in an earlier paper [23]. Yet fetal oxygen tensions do alter with maternal oxygen tensions - both in blood and in tissue particularly when the maternal level falls $[3,9,10,18,19,28,32,36]$. In many cases of fetal acidosis, however, oxygen tensions in scalp blood are normal, even when acidosis is profound $(\mathrm{pH}<7.00)$ and hypercapnia marked. This paper reports full blood-gas and acidbase measurements in 38 cases of fetal acidosis and attempts to explain the findings.

\section{Material and methods}

The hospital population is of patients selected by a stringent means test so that all are of low socio-economic class. Recent migrants and unmarried mothers are over-represented. In this already high-risk population, diagnostic fetal blood analysis was requested on the grounds of adverse clinical factors (hypertension, proteinuria, prolonged pregnancy, prolonged labor, abnormalities of fetal heart rate, retarded fetal growth).

Over 100 patients of 800 studied had fetal acidemia $(\mathrm{pH}<7.25)$. Earlier publications from the hospital used 7.20 as the lower limit of normal for $\mathrm{pH}$ as this gave better prediction of outcome than the more widely used 7.25. We have since discovered that the sterilization by $\gamma$-radiation of nylon tubes containing a heparinized cotton thread lowers the $\mathrm{pH}$ of blood subsequently collected in the tube by $0.046 \mathrm{pH}$ units. All values given here have been corrected for this factor and 7.25 adopted as the limit of normal

\section{Curriculum vitae}

JUDITH LuMLEY: Graduated from Cambridge University 1962.

Studied medicine at University College Hospital and Monash University. Graduated $M$. B., $B$. S. from latter in 1966. Researcb student in Department of Obstetrics and Gynaecology, Monash University 1967-1970.

At present, Senior Teacbing Fellow in the department.

Awarded degree of Ph. D. in 1972. Married with two children.

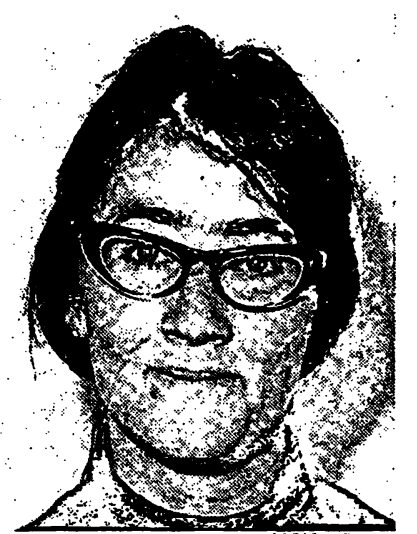

scalp blood pH. Techniques of scalp blood collection [27], blood-gas measurement and reliability [21] have been published. Discussion is limited to those patients on whom measurements of scalp blood gases were made with direct reading electrodes. A crucial element in the classification of types of acidosis is the question of the normal range. The derivation of the boundaries of the normal range and their applicability to the above population only is discussed by Lumley, MCKinNon and Wood [20].

\section{Results}

Tab. I states the limits of the normal range for the hospital population studied.

Tab. I The limits of the normal range for $\mathrm{pH}$ and blood gases in fetal scalp blood

\begin{tabular}{llll}
\hline \multicolumn{4}{c}{ Normal range } \\
\hline Oxygen & 16 & to & $31 \mathrm{mmHg}$ \\
Carbon dioxide & 28 & to & $60 \mathrm{mmHg}$ \\
$\mathrm{pH}$ & 7.25 & to & 7.45 \\
\hline
\end{tabular}


Tab. II Scalp blood gases and acid-base state in three types of fetal acidosis

\begin{tabular}{|c|c|c|c|c|c|}
\hline & pll & $\mathrm{PCO}_{\mathrm{s}}(\mathrm{mm} \mathrm{mg})$ & $\mathrm{PO}_{\mathrm{O}_{2}}\left(\mathrm{mmH} \mathrm{H}_{\mathrm{g}}\right)$ & $B \mid \dot{i}_{1}(m[q / l)$ & Argak scote \\
\hline \multirow[t]{8}{*}{ A. Asphyxial } & 6.96 & $=-100$ & 13 & $\cdots-20.0+$ & 2 \\
\hline & 7.04 & 94 & 5.5 & -9.5 & 0 \\
\hline & 7.04 & 80 & 12 & -12.0 & 3 \\
\hline & 7.08 & 92 & 9 & $\cdots 6$ & 1 \\
\hline & 7.15 & 62.5 & 5 & $\ldots 9$ & 3 \\
\hline & 7.15 & 69 & 13.5 & $\ldots .5$ & 6 \\
\hline & 7.18 & 80 & 14 & $\cdots 2$ & 5 \\
\hline & $7.18^{*}$ & 60.5 & 12.5 & -7.5 & 8 \\
\hline \multirow[t]{10}{*}{ B. Hypercapnic } & 6.64 & $>100$ & 16 & $-30+$ & 0 \\
\hline & 6.84 & $=100$ & 25 & $-23+$ & 0 \\
\hline & $7.12^{*}$ & 72 & 24 & -9 & 9 \\
\hline & $7.14^{*}$ & 60 & 16 & -10 & 6 \\
\hline & $7.14^{*}$ & 66 & 21 & -9 & 6 \\
\hline & 7.20 & 66 & 19 & -4 & 3 \\
\hline & 7.22 & 62 & 22 & -4 & - \\
\hline & $7.22^{*}$ & 64 & 23 & -3.5 & 8 \\
\hline & 7.22 & 64 & 18 & -3.5 & 2 \\
\hline & 7.23 & 65 & 19 & -2.5 & 6 \\
\hline \multirow[t]{20}{*}{ C. Metabolic } & 6.99 & 50 & 23 & -21 & 6 \\
\hline & 7.08 & 38 & 35 & -19 & 1 \\
\hline & $7.17^{*}$ & 44 & 24 & -13 & 5 \\
\hline & 7.18 & 53 & 22 & -9.5 & 6 \\
\hline & 7.18 & 49.5 & 22.5 & -10.5 & $2 / 3$ \\
\hline & 7.18 & 53 & 19 & -10.5 & 10 \\
\hline & 7.20 & 49 & 21 & -9.5 & 10 \\
\hline & 7.20 & 55 & 24 & -8 & - \\
\hline & $7.21 *$ & 52 & 38 & -8.5 & 10 \\
\hline & 7.21 & 54 & 23 & -7.5 & 7 \\
\hline & 7.22 & 48 & 41 & -9 & 8 \\
\hline & 7.22 & 41 & 21.5 & -11 & 8 \\
\hline & 7.22 & 57 & 22 & -6.5 & 7 \\
\hline & $7.22 *$ & 38 & 23 & -12 & 5 \\
\hline & 7.235 & 47 & 20 & -8.5 & 7 \\
\hline & $7.24^{*}$ & 48 & 22 & -7.5 & 5 \\
\hline & 7.24 & 39 & 19 & -10.5 & 9 \\
\hline & 7.24 & 57 & 20 & -4.5 & 5 \\
\hline & 7.24 & 57 & 17 & -4.5 & 8 \\
\hline & $7.24 *$ & 44 & 24 & -9 & 10 \\
\hline
\end{tabular}

* known to have maternal metabolic acidosis, $\mathrm{BE}<-6.5 \mathrm{mEq} / \mathrm{l}$

+ base deficit approximate, $\mathrm{PCO}_{2}$ off scale

- not recorded

Tab. II summarises the findings in 38 patients with fetal acidosis. Patients are grouped into 3 categories by their blood gases. In A (asphyxial), oxygen tensions are low and carbor dioxide tensions high. In B (hypercapnic) carbon dioxide tensions are high but oxygen tensions are normal. In C (metabolic) blood gases are normal.

Within each category the patients are listed by severity, in terms of $\mathrm{pH}$. Asphyxial acidosis, the only type which clearly fits the sequence of events understood to lead to low fetal $\mathrm{pH}$, is the least frequent. It does include four severe cases and the APGAR scores of this group are significantly lower than those of patients with purely metabolic acidosis $(p=0.003)$. The most striking feature of the table is category $B$ where there is dissociation of hypercapnia from hypoxia. This is most apparent in the first two patients listed whose carbon dioxide tensions were off 
scale while oxygen tensions were normal. (Hypoxia without hypercapnia has been found once, associated with a maternal capillary oxygen tension of $58 \mathrm{mmHg}$ ). The calculated metabolic component of the acidosis in patients with gross hypercapnia overestimates the deficit in vivo.

Metabolic acidosis with normal blood-gases was the commonest type. Most were mild $(\mathrm{pH}>7.10)$, but there are exceptions - for example those with the $\mathrm{pH} 6.99$ and 7.08. The frequent occurrence of mild metabolic acidosis explains why we have not found that the metabolic component of the acid-base state is a better index of fetal health than the $\mathrm{pH}$ is.

Maternal metabolic acidosis was fairly common. It co-existed with all types of fetal acidosis. W.e have noted maternal acidosis in many patients with transient acidosis [24] and also in patients prepared for elective Caesarean section [22]. It appears to be frequent enough to be a confusing factor in this population. In particular its frequency makes the use of $\triangle B D$ (i. e. fetal base deficit minus maternal base deficit) no advantage.

If oxygen saturations had been measured instead of oxygen tensions, all groups would have shown "hypoxia" (Tab. III) even though most patients $(79 \%)$ have normal oxygen tensions.

Saturations were derived from the nomogram of Hellegers and Schruefer [14], using the directly measured values of $\mathrm{pH}$ and $\mathrm{P}_{\mathrm{O} 2}$.

Tab. III Oxygen tensions and saturations in three types of acidosis

\begin{tabular}{lcrrr}
\hline \multicolumn{1}{c}{$\overline{\mathrm{x}}$} & $\begin{array}{c}\mathrm{P}_{\mathrm{O}_{2}} \\
(\mathrm{mmHg})\end{array}$ & $\begin{array}{c}\mathrm{O}_{2} \text { sat. } \\
(\%)\end{array}$ & $\mathrm{pH}$ & $\mathrm{n}$ \\
\hline Asphyxial & 10.5 & $<20$ & 7.10 & 8 \\
Hypercapnic & 20 & 28 & 7.10 & 10 \\
Metabolic & 24 & 43 & 7.18 & 20 \\
Normal & 23.4 & 53 & 7.35 & 12 \\
\hline
\end{tabular}

\section{Discussion}

The two problems to be resolved are (a) the dissociation of hypoxia from hypercapnia, and (b) the combination of normal blood gases with metabolic acidosis.

\subsection{Dissociation of hypoxia from hypercapnia}

The most obvious explanation is that we are either unable to measure oxygen tensions at all or that there is a systematic error in the collection/measuring system affecting low oxygen tensions in particular. This explanation cannot be excluded absolutely because no investigation of accuracy was made routinely. However several pieces of evidence suggest that the blood collection and analysis systems can be exonerated: (a) the mean and normal range of oxygen tensions in fetal scalp blood from normal patients in this hospital agrees with findings from a majority of other centres [20],

(b) oxygen tensions between 0 and $10 \mathrm{mmHg}$ have been measured in acidotic patients and in placental blood collected at Caesarean section [22],

(c) a short study of oxygen measurements on tonometered blood which was carried out over 2 months in 1970 showed a satisfactory accuracy (blood-gas factor 3.5\%),

(d) a similar case has recently been reported by ROEMER and Ruppin [30]. Before fetal death in utero the $\mathrm{pH}$ fell from $>7.25$ through 7.01 to 6.86. The $\mathrm{P}_{\mathrm{CO} 2}$ increased from 53 to $83 \mathrm{mmHg}$. The $\mathrm{P}_{\mathrm{O}_{2}}$ fell slightly from 28.5 to $23.5 \mathrm{mmHg}$.

\subsubsection{Reduced oxygen affinity}

Assuming, then, that the oxygen tensions are accurate, the likeliest explanation for normal tensions is an alteration in oxygen affinity for hemoglobin. Increase in hydrogen ion concentration or $\mathrm{P}_{\mathrm{CO} 2}$ enhances oxygen release from hemoglobin (BoHr effect). We suggested this tentatively in an earlier paper [23]. Experimental evidence supporting the hypothesis comes from two centres [13, 25]. Both groups showed that acid-infusion of the umbilical vein increased umbilical vein oxygen tensions. Tab. III shows scalp oxygen tensions in metabolic acidosis to be high, though within the normal range. The magnitude of the BoHr effect in fetal blood is shown in Tab. IV. A fall in scalp blood $\mathrm{pH}$ of $-0.5 \mathrm{pH}$ units (right hand column) i. e. 6.85 has been reported in many patients (see Tab. II, also Alvarez, Arto-Medrano and Torres [1], Bretscher and SALING [4]). Such a fall would 
shift oxygen tensions above $10 \mathrm{~mm} \mathrm{Hg}$ into the normal range.

Tab. IV. The BoHr effect in fetal blood

\begin{tabular}{crrrrr}
\hline & \multicolumn{5}{c}{$\begin{array}{c}\text { Fetal oxygen tensions (mmHg) } \\
\text { Original } \\
\text { P } \mathrm{O}_{2} \text { after a fall in pH of: }\end{array}$} \\
& -0.1 & -0.2 & -0.3 & -0.4 & -0.5 \\
\hline 5 & 5.6 & 6.2 & 6.9 & 7.6 & 8.9 \\
10 & 11.1 & 12.4 & 13.7 & 15.3 & 17.0 \\
11 & 12.2 & 13.6 & 15.1 & 16.8 & 18.7 \\
13 & 14.4 & 16.1 & 17.9 & 19.9 & 22.1 \\
15 & 16.7 & 18.5 & 20.6 & 22.9 & 25.5 \\
20 & 22.2 & 24.7 & 27.5 & 30.6 & 34.0 \\
25 & 27.8 & 30.9 & 34.3 & 38.2 & 42.4 \\
\hline
\end{tabular}

Calculated from $\frac{\Delta \log \mathrm{PO}_{2}}{\Delta \mathrm{pH}}=0.064$ (HILPERT, FleischMANN, KEMPE and BARTELS [16]) assuming that this is valid over the whole range of tensions/saturations and that no other factors alter oxygen affinity.

Simultaneously, however acidosis inhibits redcell glycolysis and leads to a fall in DPG (2'3 diphosphoglycerate). This fall decreases oxygen availability (RAPOPORT [29], MINIKAMI [26]) reversing the BoHR effect after a few hours. The BoHr effect would therefore be most applicable to findings in acute asphyxia e. g. antepartum hemorrhage. This was in fact the clinical finding in the first 2 hypercapnic patients of Tab. II.

A diffusible factor reducing oxygen affinity (not $\mathrm{pH}$, ATP or 2'3 DPG but otherwise unidentified) has been detected in the coronary circulation during attacks of angina pectoris [35]. It was not present in the general circulation. Such a factor would be particularly helpful in explaining tension differences between scalp and umbilical cord blood. The hypothesis that normal-high oxygen tensions in fetal acidosis are due to changes in oxygen affinity could be tested by measuring the $\mathrm{P}_{50}$ (the tension at which oxygen saturation is $50 \%$ ) in scalp blood. This is potentially a useful diagnostic test since in the adult it is "the best indicator of tissue hypoxia" [8].

\subsubsection{Fall in oxygen consumption}

The contribution of reduced oxygen consumption to maintaining oxygen tensions in carotid blood is well described in fetal lambs [7, 5]. It depends on the fact that fetal arterial blood consists of umbilical vein blood diluted by blood from the trunk and lower limbs. If there is a fall in oxygen consumption in non-vital areas associated with a reduction in blood flow the oxygen tension of venous blood from the lower half of the body will be relatively high. This will minimise the fall in oxygen tension which precipitated the fall in oxygen consumption [6]. Saling has discussed this " $\mathrm{O}_{2}$ conserving mechanism" in detail $[33,34]$, and the changes in blood flow have been analysed by RuDolph [31] using the distribution of radioactive microspheres. Similar changes in blood flow which occur when a lamb fetus is delivered from the uterus before the placenta separates may be sufficient to increase the oxygen tension above normal [15]. The oxygen tensions in hypercapnic acidosis (Tab. II) although within the normal limits derived from healthy patients, are lower than the mean (20.2 as opposed to $23.4 \mathrm{~mm} \mathrm{Hg}$ ). They would be compatible with true asphyxia (reduction in oxygen, excess carbon dioxide) at placental and cord levels modified by the fall in oxygen consumption and reduced oxygen affinity described above.

\subsection{Normal blood gases with metabolic acidosis}

The second aetiological problem, that of metabolic acidosis in the fetus with normal blood gases and normal maternal acid-base state, has been ascribed to intermittent interference with blood gases causing gradual metabolic acidosis (as can easily be imagined when the umbilical cord is compressed either during contractions or in a particular posture). One would have to assume that the scalp samples always miss the period(s) of hypoxia and hypercapnia. However this group shows no evidence of even a trend towards hypercapnia and the oxygen tensions are higher than normal. Two studies of scalp blood measurements associated with nuchal cord $[11,12]$ show that the characteristic pattern is pure respiratory acidosis. (Neither measured oxygen tensions.) The facts that pure metabolic acidosis is found in asso- 
ciation with retarded fetal growth and that such acidosis has a relatively good prognosis suggests that there are feto-placental, non-asphyxial causes of fetal acidosis.

We conclude that changes in oxygen affinity and oxygen consumptipn can account for normal oxygen tensions with hypercapnia in fetal acidosis but there are also non-asphyxial forms of acidosis which may in some populations be the commonest type.

\section{Summary}

Why are fetal scalp blood oxygen tensions such a poor guide to the state of the fetus? In many cases of fetal acidosis, oxygen tensions in scalp blood are normal, even when acidosis is profound $(\mathrm{pH}<7.10)$ and hypercapnia marked. This paper sets out to classify 38 cases of fetal acidosis in terms of the normality or otherwise of their blood-gases and to suggest an answer for the question posed above.

The patients whose measurements are discussed are from ia hospital population selected by stringent means test. In addition, each had some adverse clinical factor for which diagnostic fetal blood analysis was requested. The limits of the normal range for this population have already been established. They are $7.25(\mathbf{p H}), 16 \mathrm{~mm} \mathrm{Hg}\left(\mathrm{P}_{\mathrm{O}_{2}}\right)$ and $60 \mathrm{~mm} \mathrm{Hg}\left(\mathrm{P}_{\mathrm{CO}_{2}}\right)$ (Tab. I).

There are three categories in the classification (Tabs. II-III). A (asphyxial) includes all whose oxygen tensions are low and carbon dioxide tensions high. In B (hypercapnic) carbon dioxide are high but oxygen tensions are normal. In C (metabolic) blood gases are normal.

Asphyxial acidosis, the type which best fits the sequence of events understood to lead to the development of low $\mathrm{pH}$, is the least frequent and the most severe.

The ten patients in category $\mathbf{B}$ are the most striking, showing dissociation of hypoxia from hypercapnia. The two most severe cases ( $\mathrm{pH} 6.64$ and 6.84) both had carbon dioxide tensions too high to be measured, and oxygen tensions of 16 and $25 \mathrm{~mm} \mathrm{Hg}$ respectively.

Metabolic acidosis was the most frequent and the least severe, though profound acidosis was recorded twice in this group.

Maternal metabolic acidosis was common. It coexisted with all types of fetal acidosis. The frequent occurrence of mild fetal metabolic acidosis and maternal acidosis in the population studied may account for our failure to confirm that base deficit or $\Delta$ base deficit are better predictors of fetal outcome than the ApGar score is.

The discussion centres around two problems (1) the dissociation of hypercapnia from hypoxia and (2) the combination of normal blood gases with metabolic acidosis. Assuming that the oxygen tensions measured are reasonably accurate (because the mean and range agree with those of a majority of other centres) the likeliest explanation for "normal" oxygen tensions is an alteration in the affinity of hemoglobin for oxygen. The best known example of such a change is the BOHR effect in which an increase in hydrogen ion concentration or $\mathrm{P}_{\mathrm{CO}_{2}}$ enhances oxygen release from hemoglobin. The magnitude of the BoHr effect in fetal blood is shown in Tab. IV. The magnitude and time course of the effect could shift oxygen tensions above $10 \mathrm{~mm} \mathrm{Hg}$ into the normal if asphyxia were acute.

The contribution of reduced oxygen consumption to maintaining oxygen tensions, well documented in fetal lambs, is discussed.

Metabolic acidosis with normal bloodgases may be explained by intermittent interference with umbilical cord blood flow - though studies of nuchal cord suggest that hypercapnia is an early result of cord compression. Alternatively there are feto-placental, non-asphyxial causes of fetal acidosis.

Keywords: acidosis, Bohr effect, fetus, oxygen affinity, oxygen tension.

\section{Zusammenfassung}

Unerwartete Sauerstoffspannungswerte in Fällen fetaler Azidose

Weshalb sind Sauerstoffspannungswerte aus fetalem Kopfschwartenblut ein so unzureichender Hinweis auf den Zustand des -Feten? In vielen. Eällen fetaler Azidose ist die Sauerstoffspannung im Kopfschwartenblut normal, selbst bei schwerer Azidose $(\mathrm{pH}<7,10)$ und ausgeprägter Hyperkapnie. Diese Arbeit versucht 38 Fälle fetaler Azidose aufzuteilen in Normalfälle und pathologische Fälle je nach ihren Blutgaswerten und bietet eine Antwort auf die oben gestellte Frage an.

Die Patienten, deren Meßwerte diskutiert wurden, sind nach strengen Testmethoden aus einer Krankenhauspopulation ausgewählt. Außerdem trat in allen Fällen eine ungünstige klinische Situation auf, die eine Fetalblutanalyse notwendig machte. Die Grenzen der Normalwerte für diese Population wurden bereits aufgestellt; sie betragen $7,25(\mathrm{pH}), 16 \mathrm{~mm} \mathrm{Hg}\left(\mathrm{PO}_{2}\right)$ und $60 \mathrm{~mm} \mathrm{Hg}\left(\mathrm{P}_{\mathrm{CO}_{2}}\right)$ (Tab. I). Es werden drei Gruppen voneinander unterschieden (Tab. II-III): Gruppe A (asphyktisch) umfaßt alle Fälle mit niedriger Sauerstoffspannung und hoher $\mathrm{CO}_{2}$ Spannung. Bei Gruppe B (hyperkapnisch) ist die $\mathrm{CO}_{2}-$ Spannung hoch, die Sauerstoffspannung aber normal. Bei Gruppe C (metabolisch) sind die Blutgase normal. 
Die asphyktische Azidose, jencr Typ, den man am besten mit $\mathrm{pH}$-senkenden Ereignissen in Verbindung bringen kann, kommt am wenigsten vor und ist die schwerste.

Dic 10 Patienten der Gruppe B fallen am meisten auf, denn sic zeigen das Fehlen einer Hypoxic bei bestehender Hyperkapnie. Die beiden schwersten Fälle ( $\mathrm{pH} \mathrm{6,64} \mathrm{und}$ $6,84)$ zeigten beide $\mathrm{CO}_{2}$-Spannungen, die oberhalb des noch meßbaren Bereiches lagen, wobei die Sauerstoffspannung 16 bzw. $25 \mathrm{~mm} \mathrm{Hg}$ betrug.

Am seltensten und von geringstem Schweregrad war die metabolische Azidose, obgleich sich in dieser Gruppe zwei Fälle von schwerer Azidose befanden.

Eine metabolische Azidose der Mutter trat am häufigsten auf; sie kam bei allen Arten fetaler Azidose vor. Das häufige Auftreten leichter fetaler metabolischer Azidosen und mütterlicher Azidosen in der untersuchten Gruppe mag der Grund dafür sein, daß es uns mißlang zu bestätigen, daß das Basendefizit bzw. das $\triangle$-Basendefizit ein besseres Kriterium für den fetalen Zustand sei als der APGAR Score.

Die Diskussion konzentriert sich auf 2 Probleme, 1. das getrennte Auftreten von Hyperkapnie und Hypoxie und 2. das kombinierte Vorkommen von normalen Blutgasen mit einer metabolischen Azidose. Nimmt man an, die gemessenen Sauerstoffspannungen sind hin- reichend genau (denn Mittelwerte und Streubreite stimmen mit jenen der meisten anderen Zentren überein), so ist die naheliegendste Erklärung für die „normale“ Saucrstoffspannungen eine Veränderung der Affinität des Hämoglobins zum Sauerstoff. Das bekannteste Beispiel ciner solchen Affinitäts-Ånderung ist der BoHr-Effekt, bei welchem eine Vermehrung der Wasserstoffionenkonzentration oder des $\mathrm{PCO}_{2}$ eine Sauerstoffabgabe des Hämoglobins zur Folge hat. Das Ausmaß des BoHR-Effektes im fetalen Blut ist in Tab. IV dargestellt. Größe und Zeitverlauf dieses Effektes ermöglichen die Verschiebung einer Sauerstoffspannung von über $10 \mathrm{~mm} \mathrm{Hg}$ bis in den Normalbereich, wenn eine akute Asphyxie auftritt.

Die Möglichkeit, durch eingeschränkten Sauerstoffverbrauch die (normale) Sauerstoffspannung aufrecht zu erhalten, wie dies bei Schaf-Feten gut belegt ist, wurde diskutiert.

Die metabolische Azidose bei normalen Blutgaswerten könnte durch eine intermittierende Störung der Nabelschnurdurchblutung erklärt werden, obgleich Untersuchungen am Nackenband die Hyperkapnie als eine frühe Folge der Nabelschnurkompression erscheinen lassen. Andererseits gibt es feto-plazentare, nicht apshyktische Ursachen für eine fetale Azidose.

Schlüsselwörter: Azidose, Bohr-Effekt, Fetus, Sauerstoffaffinität, Sauerstoffspannung.

\section{Resumé}

Tensions d'oxygène imprévues dans des cas d'acidose foetale

Pourquoi les tensions d'oxygène du sang foetal prélevé sur le cuir chevelu donnent-elles des renseignements aussi mauvais sur l'état du foetus? Dans beaucoup de cas d'acidose foetale, les tensions d'oxygène du sang du cuir chevelu sont normales même si l'acidose est profonde ( $\mathrm{pH}<7.10$ ) et l'hypercapnie marquée. Cet article propose de classifier 38 cas d'acidose foetale par rapport à la normal et leurs gaz sanguins et de donner une réponse à la question posée plus haut.

Les patientes, dont les résultats sont discutés, ont été choisies parmi une population hospitalière sélectionnée par des épreuves sévères. En plus, chacune avait un facteur défavorable pour motiver une analyse du sang foetal. Les limites de la valeur normale pour ce groupe ont déjà été établies. Elles sont de 7,25 (pH), $16 \mathrm{~mm} \mathrm{Hg}\left(\mathrm{P}_{2}\right)$ et de $60 \mathrm{~mm} \mathrm{Hg}\left(\mathrm{PCO}_{2}\right)$ (tab. I).

Nous avons établi trois catégories (tabs. II-III):

A. (Asphyxie) englobe tous les cas où les tensions d'oxygène sont basses. et.les. $\mathrm{P}_{\mathrm{CO}}$ élevéées.

B. (Hypercapnie) la $\mathrm{PCO}_{2}$ est élevée mais les $\mathrm{PO}_{2}$ sont normales.

C. (Métabolique), les gaz sanguins sont normaux.

L'acidose asphyxique, responsable du développement d'un $\mathrm{pH}$ abaissé, est la moins fréquente et la plus sévère (A). Les 10 patientes de la catégorie $\mathbf{B}$ sont les plus frappantes, montrant une dissociation entre l'hypoxie et l'hypercapnie.
Les 2 cas les plus sévères ( $\mathrm{pH} 6.64$ et 6.84) avaient tous les deux des $\mathrm{PCO}_{2}$ trop élevées pour être mesurées et des $\mathrm{PO}_{2}$ respectivement de 16 et $25 \mathrm{mmHg}$.

L'acidose métabolique (C) était la plus fréquente et la moins sévère, bien qu'une acidose profonde eût été enregistrée à deux reprises dans ce groupe.

L'acidose métabolique maternelle était courante. Elle co-existait avec tous les types d'acidose foetale. L'association fréquente d'une acidose métabolique foetale légère et d'une acidose maternelle dans le groupe étudié peut expliquer notre échec pour prouver que l'excès de base négatif ou le $\Delta$ excès de base soient des meilleurs indices de l'état foetal que le score d'APGAR.

La discussion tourne autour de 2 problèmes:

1. la dissociation entre l'hypercapnie et l'hypoxie et 2. l'association des gaz sanguins normaux avec l'acidose métabolique.

Supposant que les pressions d'oxygène mesurées sont à peu près justes, (vu que nos valeurs moyennes concordent avec celles d'une majorité d'autres centres), l'explication la plus probable pour les $\mathrm{PO}_{2}$ «normales» est une modification de l'affinité de l'hémoglobine pour l'oxygène. L'exemple le plus connu d'un tel changement est l'effet BoHr dans lequel une augmentation de la concentration du ion-hydrogène ou de la $\mathrm{PCO}_{2}$ augmente l'oxygène libéré de l'hémoglobine. L'importance de l'effet BoHR dans le sang foetal est montré dans un tableau (tab. IV). La force 
et la durée de l'effet pourrait porter $\mathrm{la}_{\mathrm{P}_{2}}$ dans le domaine du normal si l'asphyxie était aiguë.

Le rôle de la consommation réduite d'oxygène pour maintenir une $\mathrm{P}_{2}$, bien documentée dans les foetus d'agneaux, est discutée.

L'acidose métabolique avec des gaz sanguins normaux peut être expliquée par des altérations passagères de la circulation ombilicale - cependant des études avec des circulaires du cordon suggèrent que l'hypercapnie est une conséquence rapide de la compression du cordon. Alternativement il $\mathrm{y}$ a des causes foeto-placentaires non-asphyxiques à l'acidose foetale.

Mots-clés: acidose, effet Bohr, foetus, affinité oxygénique, pression partielle en oxygène.

\section{Bibliography}

[1] Alvarez, C. J. A., F. Arto-Medrano, A. V. Torres: Acidosis graves del feto durante el parto. Acta Obstet. Ginec. Hisp.-Lus. 1 (1970) 21

[2] Arto-Medrano, F.: Influence of cord atound the neck on fetal acid-base balance in vigorous newborn infants. Amer. J. Obstet. Gynec. 107 (1970) 1035

[3] Bretscher, J., E. Saling: Der Einfluß einer Sauerstoffatmung der Mutter auf den Feten. Anaesthesist 15 (1966) 136

[4] Bretscher, J., E. Saling: Azidotische Extremwerte beim menschlichen Fetus. Zbl. Gynäk. 91 (1969) 31

[5] Campbeli, A. G. M., G. S. Dawes, A. P. Fishman, A. I. Hyman: Regional redistribution of blood flow in the mature fetal lamb. Circulation Res. 21 (1967) 229

[6] Dawes, G. S.: Foetal and Neonatal Physiology. Year Book Medical Publishers, Chicago 1968

[7] Dawes, G. S., J. C. Mотт: Changes in $\mathrm{O}_{2}$ distribution and consumption in foetal lambs with variations in umbilical blood flow. J. Physiol. 170 (1964) 524

[8] Edwards, J. M., M. J. Novy, C.-L. Walters, J. MeTCALFE: Improved oxygen release: an adaption of mature red cells to hypoxia. J. Clin. Invest. 47 (1968) 1851

[9] Frangipani, G. C., B. A. Samaja, A. Tintr: Lattacidemia, piruvicemia ed equilibrio acido-base materno fetali in travaglio di parto. II. Durante iperossigenazione materna. Annali Ostet. Ginec. 91 (1969) 14

[10] Gare, D. J., J. Shime, W. M. Paul, M. Hoskins: Oxygen administration during labor. Amer. J. Obstet. Gynec. 105 (1969) 954

[11] Gentile, D., A. Piccolomini, G. Pelusi: La componente metabolica dell'equilibrio acido-base fetale in travaglio di parto. Riv. ital. Ginec. 51 (1967) 392

[12] Gulin, L. A., L. A. Escarcena, S. V. Pose: Relaciones del oxigeno de la sangre capilar fetal con la frecuencia cardiaca fetal y el indice de Apgar del recien nacido. Obstet. Ginec. lat.-am. 26 (1968) 20

[13] Hellegers, A. E., E. E. Armstead, C. E. Thomas, A. M. Burnett, T. J. Magovern, P. D. Bruns: Effect of fetal metabolic acidosis upon oxygen environment. Amer. J. Obstet. Gynec. 105 (1969) 786

[14] Hellegers, A. E., J. J. P. Schruefer: Nomograms and empirical equations relating oxygen tension, percentage saturation and $\mathrm{pH}$ in human maternal and fetal blood. Amer. J. Obstet. Gynec. 81 (1961) 377
[15] Heymann, M. A., A. M. Rudolph: The effect of exteriorisation of the sheep fetus on its cardiovascular function. Circulation Res. 21 (1967) 741

[16] Hilpert, P., R. G. Fleischmann, D. Kempe, H. BARTELS: The BoHr effect related to blood and erythrocyte pH. Amer. J. Physiol. 205 (1963) 337

[17] Kerenyi, T. D., S. Falk, R. D. Mettel, B. Walker: Acid-base balance and oxygen saturation of fetal scalp blood during normal and abnormal labors. Obstet. Gynec. N. Y. 36 (1970) 398

[18] Khazin, A. F., E. H. Hon, F. W. Hehre: Effects of maternal hyperoxia on the fetus. 1. Oxygen tension. Amer. J. Obstet. Gynec. 109 (1971) 628

[19] KüNZEL, W., H. Wulf, A. Busse: Der Einfluß der maternen Ventilation auf die aktuellen Blutgase und den Säure-Basen Status des Feten. Z. Geburtsh. Gynäk. 172 (1970) 1

[20] Lumley, J., L. McKinnon, C. Wood: Lack of agreement on normal values for fetal scalp blood. J. Obstet. Gynaec. Brit. Cwlth. 78 (1971) 13

[21] Lumiex, J., M. Potter, W. Newman, J. Talbot, E. WAKEFIELD, C. WOOD: The unreliability of a single estimation of fetal scalp blood $\mathrm{pH}$. J. Lab. Clin. Med. 77 (1971) 535

[22] Lumlex, J., A. Walker, J. Marum, C. Wood: Time: an important variable at Caesarean section. $\mathrm{J}$. Obstet. Gynaec. Brit. Cwlth. 77 (1970) 10

[23] Lumlex, J., C. Wood: Fetal acidosis. Aust. N. Z. J. Obstet. Gynaec. 9 (1969) 145

[24] Lumley, J., C. Wood: Transient fetal acidosis and artificial rupture of the membranes. Aust. N. Z. J. Obstet. Gynaec. 11 (1971) 221

[25] Meschia, G., F. C. Battaglia, E. L. Makowski, W. Droegmueller: Effect of varying umbilical blood $\mathrm{P}_{2}$ affinity on umbilical vein $\mathrm{P}_{\mathrm{O}_{2}}$. J. appl. Physiol. 26 (1969) 410

[26] Minikami, S.: Regulation of glycolysis in human red cells. In: Deutsch, E., E. Gerlach, K. Moser: Metabolism and Membrane Permeability of Erythrocytes and Thrombocytes. Thieme, Stuttgart 1968

[27] Newman, W., D. Braid, C. Wood: Fetal acid-base status. I. Relationship between maternal and fetal $\mathrm{P}_{\mathrm{CO}_{2}}$. Amer. J. Obstet. Gynec. 97 (1967) 43

[28] Newman, W., L. McKinnon, L. Phillips, P. Paterson, C. Wood: Oxygen transfer from mother to fetus during labor. Amer. J. Obstet. 'Gynec. 99 (1967) 61 
[29] RAPOPORT, S.: The regulation of glycolysis in mammalian erythrocytes. Essays Biochem. 1 (1965) 69

[30] Roemer, V. M., E. Ruppin: Blutgasanalytische, elektro- und kardiotokographische Befunde bei einem Fall von schwerer intrauteriner Asphyxie. Geburtsh. u. Frauenheilk. 31 (1971) 853

[31] Rudolph, A. M.: The course and distribution of the fetal circulation. In: Wolstenfolme, G. E. W., M. O'Connor: Foctal Autonomy. Churchill, London 1969

[32] Saling, E.: Die Wirkung einer $\mathrm{O}_{2}$-Atmung der Mutter auf die Blutgase und den Säure-Basen-Haushalt des Feten. Geburtsh. u. Frauenheilk. 23 (1963) 528
[33] Saling, E.: Dic $\mathrm{O}_{2}$-Sparschaltung des fetalen Kreislaufes. Geburtsh. u. Frauenheilk. 26 (1966) 413

[34] Saling, E.: Foetal and Neonatal Hypoxia in relation to clinical obstetric practice. Arnold, London 1968

[35] Shappell, S. D., J. A. Murray, M. G. Nasser, R. E. Wills, J. D. Torrance, C. J. M. Lenfant: Acute change in hemoglobin affinity for oxygen during angina pectoris. New Engl. J. Med. 282 (1970) 1219

[36] Walker, A., L. Maddern, E. Day, P. Renou, J. TALBOT, C. WoOD: Fetal scalp oxygen tissue tension measurements in relation to maternal dermal oxygen tension and fetal heart rate. J. Obstet. Gynaec. Brit. Cwlth. 78 (1971) 1

Judith Lumley M. B., B. S., Ph. D. Dept. of Obstctrics and Gynecology Monash University Queen Viktoria Hospital Melbourne, Viktoria, Australia 